\title{
Hong Kong, 1997, and the International Movement of Antiquities
}

Introduction

Many collectors, dealers, and museum professionals would maintain that China is the final frontier for the art and cultural property ${ }^{1}$ trade. Its potential, not just as a source but also as a future market, is huge. ${ }^{2}$ The very existence of a thriving contemporary art market only serves to underscore the enormous importance of the vastly more lucrative antiquities trade.

The People's Republic of China ('PRC') is undoubtedly now the classic 'source' state in an art world divided into rich, developed, but art-poor 'market' states and poor, developing, but art-rich 'source' states. It is a developing

1 'Cultural property' may be loosely defined as a category of property that includes works of art and archaeological, historical, and ethnological objects which are generally considered as being the material evidence of a certain stage of civilisation: Pierre Lalive, 'A General View of the Law Relating to Cultural Property' (1988) 13 International Legal Practitioner 18. There is an infinite variety of definitions found in domestic legislation around the world.

The extended definition of 'cultural property' contained in Art 1 of the UNESCO Convention on the Means of Prohibiting and Preventing the Illicit Import, Export and Transfer of Ownership of Cultural Property 1970, 823 UNTS (hereinafter, the '1970 UNESCO Convention'), a definition often regarded as subjective and overbroad for practical purposes, enumerates various categories of 'property which, on religious or secular grounds, is specifically designated by each State as being of importance for archaeology, prehistory, history, literature, art or science ...'

The terminology used in the People's Republic of China is normally 'cultural relics' rather than 'cultural property.' Article 2 of the Law of the People's Republic of China on the Protection of Cultural Relics, adopted at the 25th Meeting of the Standing Committee of the Fifth National People's Congress and promulgated 19 November 1982 by Order No 11 of the Standing Committee of the National People's Congress (hereinafter, 'the 1982 Cultural Relics Law' or '1982 Law'), is as follows:

Article 2The state shall place under its protection, within the boundaries of the People's Republic of China, the following cultural relics of historical, artistic or scientific value:

(1) sites of ancient culture, ancient tombs, ancient architectural structures, cave temples and stone carvings that are of historical, artistic or scientific value;

(2) buildings, memorial sites and memorial objects related to major historical events, revolutionary movements or famous people that are highly memorable or are of great significance for education or for the preservation of historical data;

(3) valuable works of art and handicraft articles dating from various historical periods;

(4) important revolutionary documents as well as manuscripts and ancient or old books and materials, etc, that are of historical, artistic or scientific value; and

(5) typical material objects reflecting the social system, social production or the life of various nationalities in different historical periods.

By contrast, the Hong Kong Antiquities and Monuments Ordinance, legislation that deals largely with site designation rather than with the movement of antiquities, and which does not refer directly to any criteria of cultural significance, defines 'antiquity' (in s 2) as '(a) a relic; and (b) a place, building, site or structure erected, formed or built by human agency before the year 1800 and the ruins or remains of any such place, building, site or structure, whether or not the same has been modified, added to or restored after the year 1799.' A 'relic' is defined as (a) a movable object made, shaped, painted, carved, inscribed or otherwise created, manufactured, produced or modified by human agency before the year 1800 , whether or not it has been modified, added to or restored after the year 1799 ; and (b) fossil remains or impressions.

2 It is interesting to compare and contrast the situation in Russia after 'glasnost.' There, economic relaxations led immediately to the intervention of Western art dealers and auction houses, Western art exhibitions, concern about overvaluation, and confusion as to world trading practices and commercialisation of art generally. The situation eventually prompted the re-entry of government with a view to taking over art as an export barter commodity: see Julie S Berkowitz, 'A Look Into Glasnost's Impact on the Soviet Art World' (1991) 11 Loyola Entertainment Law Journal 453. 
country awakening - both at the private and governmental levels - to the economic potential of the antiquities trade. The economic significance of its relics is increasing while their cultural significance has declined. There is a huge supply in government storage and as yet unexcavated or undiscovered in tombs. Grave-robbing and museum thefts occur on a massive scale. The PRC is increasingly the target of international smuggling networks (with peasants at the bottom of the pyramid and dealers and collectors at the top). There are inadequate state resources for conservation, archaeology, or protection. There is little hope of effectively enforcing blanket export restrictions. Empirically, the lack of a free licit market has made large-scale black marketeering inevitable, with attendant social problems of corruption and the devastation of sites. ${ }^{3}$ Many of the current problems and themes in the cultural property area generally are magnified in the PRC.

Hong Kong has always played an important role in the movement of antiquities out of China and is intimately connected with the Chinese antiquities trade. ${ }^{4}$ This brief note provides an overview of the PRC legal regime and considers what impact the reversion to the PRC in 1997 of sovereignty over Hong Kong will have on the international movement of cultural property.

\section{The movement of Chinese antiquities into and through Hong Kong}

Hong Kong has long been recognised as the leading 'transit' state for PRC antiquities, and, indeed, a 'market' state. It is a centre for all facets of the art trade - expertise, appraisal, finance, sales and auction facilities, and transportation. A significant volume of the illicit traffic from China - antiquities stolen or illegally exported - flows out through Hong Kong.

Not least important is the fact that Hong Kong has virtually no import or export controls aimed at art and cultural property. The importing of antiquities

3 See J David Murphy, 'The People's Republic of China and the Illicit Trade in Cultural Property: Is the Embargo Approach the Answer?' (1993) 2 Asia Pacific Law Review 53, reprinted in (1994) 3 International Journal of Cultural Property (forthcoming); J David Murphy, 'The Imperilment of Cultural Property in the People's Republic of China,' paper presented at 'Material Culture in Flux - Repatriation of Cultural Property: A Conference on International and Domestic Law and Policy,' University of British Columbia, Vancouver, Canada, May 1994; and J David Murphy, Let The Past Serve The Present: Cultural Property Law and Practice in the People's Republic of China (forthcoming in 1995).

4 Interestingly, a Chinese commentator distinguishing between 'precious' relics (normally those within the first, second, or third grades, as administratively determined by the PRC State Bureau of Cultural Relics) and 'ordinary' relics (normally those dated after 1795, without historical, artistic, or scientific value), equated the latter with objects for which 'there is no great demand ... in the markets of HongKong ...':Chen Shun-lie, 'The Legal Basis to Punish Cultural Relics Crimes Severely' (1988) 4 Studies in Law 40-5 (in Chinese).

5 On the concept of the transit state, see Lyndel V Prott and Patrick J O'Keefe, Law and the Cultural Heritage (London: Butterworths, 1989), vol 3, ch 10; Karen T Burke, 'International Transfers of Stolen Cultural Property: Should Thieves Continue To Benefit from Domestic Laws Favoring the Bona Fide Purchaser?' (1990) 13 Loyola of Los Angeles International and Comparative Law Journal 427; and Patrick JO'Keefe, 'Commonwealth Co-operation for the Preservation of Cultural Heritage' in Commonwealth Law Conference Proceedings 1993, p 643. Interestingly, Art 16 of the 1978 UNESCO Recommendation for the Protection of Movable Cultural Property would have imposed specific duties on transit states. 
into Hong Kong, or their export, are not per se illegal under Hong Kong law, though movement of bulk shipments of items for trade into or out of Hong Kong without a manifest (smuggling) could constitute an offence. ${ }^{6}$ As a matter of practice, Hong Kong authorities usually return to the PRC smuggled antiquities they have seized, presumably as a matter of comity. ${ }^{7}$ Otherwise, the relics are regarded as 'home free' when they find their way into the hands of dealers or other intermediaries in Hong Kong.

As to the only legislation dealing specifically with cultural property, it seems clear from s 20(2)(b) of the Antiquities and Monuments Ordinance that antiquities that have been 'imported into Hong Kong' are not intended to be subject to the control or protection provisions of the ordinance.

Antiquities are thought to be the largest single class of item smuggled out of the PRC, at least in terms of monetary value. ${ }^{8}$ Historically, smuggling relics out of the PRC has proven to be relatively easy. A commonly-used route is via the province of Guangdong ${ }^{9}$ with a view to transshipment through neighbouring Hong Kong or Macau. Relics are frequently smuggled out of the PRC by coastal vessels, including the myriad small cargo and fishing boats sailing in the South China Sea. They are also brought into Hong Kong in truck cargo, or, in the case of extremely valuable individual pieces, couriered out of the country by plane.

Import and Export Ordinance, s 18. Items of ivory are banned from import or export under the Animals and Plants (Protection of Endangered Species) Ordinance, which gives effect in Hong Kong to the Convention on International Trade in Endangered Species of Wild Fauna and Flora. The United Kingdom is not a party to the 1970 UNESCO Convention on the Means of Prohibiting and Preventing the Illicit Import, Export and Transfer of Ownership of Cultural Property; this is a sore point with the international cultural property community generally, given the status of London in the international art trade, but it also has implications for Hong Kong's position as a transit state.

7 Hong Kong Customs assume that the government of the PRC is the owner of the relics, and repatriation is arranged through the Hong Kong office of the New China News Agency, the de facto PRC consulate. It has been reported that the PRC has 'rewarded' the work of Hong Kong's law enforcement agencies in returning smuggled artifacts by donating to the Hong Kong Museum of Art numerous pieces of antique porcelain from the National Museum of Chinese History: South China Morning Post, 9 April 1991 (but see the official PRC rationale for the donation in 'China's Museum Donates Ceramics to Hong Kong,' Xinhua (New China News Agency), 7 February 1991). Hong Kong customs authorities used to call upon curators at the Hong Kong Museum of Art to verify the nature and value of the items seized; however, the curators now resist in view of the large number of items that are brought to them on a regular basis. Lower grade relics are often seized in batches of hundreds. Expositions, Art Asia: Hong Kong (Hong Kong: Everbest Printing Co Ltd, 1992), p 11. Relic smuggling out of China has even come to be romanticised in recent popular fiction: see Justin Scott, Nine Dragons (New York: Bantam, 1991).

9 A local saying is 'East, south, west, north, or central, by sea, land or air, smuggle cultural relics to Guangdong': Fazhi Ribao (Legal System Daily), 7 February 1992, p 3. From 1981 to 1989, Guangdong Customs investigated 3,081 cases of relics smuggling and retrieved 70,226 items. In a typical recent case, Guangzhou Customs, inspecting a container truck carrying goods for export, found among the goods seven large boxes of cultural relics of the Han, Tang, Yuan, Ming, and Qing dynasties, all of which were prohibited exports, and 329 pieces of Grade Three relics from the collections of museums. An official of the Guangdong Provincial Cultural Relics Administration Committee acknowledged that in 1991 in Guangdong, Public Security and Customs recovered 2,000 prohibited relics and 5,600 ordinary relics: Xu Heng-bin, quoted in Da Gong Bao (in Chinese), 24 October 1992, p 6. 
In September 1993 Hong Kong officers at Lok Ma Chau seized 107 artifacts worth more than HK\$10 million. ${ }^{10}$ In April 1994 a shipment worth considerably more, consisting of 250 pieces including bronze buddhas, swords, and terracotta animals, was seized at the border. ${ }^{11}$ Hong Kong dealers recall the heyday of the mid-1980s when boxes of antiques were unloaded in Hong Kong from mainland cargo ships each night. ${ }^{12}$ Smuggling into Hong Kong may not be as brazen in recent times, but there is no doubt that a steady flow continues. It is widely alleged that many of the smuggling rings are based in Hong Kong or in Macau, using a network of antique dealers to obtain the highest prices. ${ }^{13}$ Sales of the most valuable pieces, which are often couriered into Hong Kong individually, are said to be arranged between local dealers and overseas buyers without the item ever appearing in a local shop. Hong Kong customs officials complain that they receive little co-operation from Hong Kong art traders, and that the likelihood of low-level smugglers or couriers informing on ring-leaders is very slim.

Hong Kong Customs and Excise Department statistics indicate that between 1983 and 1993 there were fifty court cases in Hong Kong involving relics smuggling. Thirty-seven of them involved sea vessels and the rest involved trucks and containers. Almost seven thousand pieces were smuggled. ${ }^{14}$ The generally low sentences (usually fines around $\mathrm{HK} \$ 10,000$ ) meted out by Hong Kong courts suggest that such smuggling is regarded as a minor economic crime.

An overview of the PRC legal regime relating to cultural relics

As one of the main issues of concern is whether PRC laws relating to cultural relics will apply to the Hong Kong Special Administrative Region after 30 June 1997, the following paragraphs briefly summarise the main features of the current PRC legal regime relating to cultural property. ${ }^{15}$

The National People's Congress, the supreme legislative organ, has not dealt directly with cultural property matters except in the Criminal Law of the People'sRepublic of China, ${ }^{16}$ Articles 173 and 174 of which deal with defacing,

South China Morning Post, 25 September 1993.

South China Morning Post, 17 April 1994.

South China Morning Post, 9 October 1992.

13 Chinese commentaries often allege that the largest smuggling cases are 'incited and controlled by the merchants and smugglers from Hong Kong and Macau': Chen shun-lie (note 4 above). PRC Public Security Bureau officers often pose as 'Hong Kong bosses.'

14 Customs and Excise statistics in the author's files.

15 For an examination of the array of laws, regulations, notices, rules, and orders that touch upon cultural property matters in the PRC generally, see J David Murphy, Let The Past Serve The Present (note 3 above), especially ch 4; J David Murphy, 'Annotated Chronological Index of People's Republic of China Statutory and Other Materials Relating to Cultural Property' (1994) 3 International Journal of Cultural Property 159; and J David Murphy, 'The 1982 Law of the People's Republic of China on the Protection of Cultural Relics,' paper delivered at a meeting of Committee 20 (Cultural Property), Section on General Practice, International Bar Association Biennial Conference, Melbourne, October 1994.

16 Adopted by the Second Session of the Fifth National People's Congress on 1 July 1979 and effective as of 1 January 1980. 
stealing, and exporting relics, and generally criminalise violations of other cultural relics laws. Most of the main legislation in the cultural property area, including the central statute, the Law of the People's Republic of China on the Protection of Cultural Relics, ${ }^{17}$ emanates from the Standing Committee of the National People's Congress. Many norms (for example, the Circular on Cracking Down on Activities Involving Smuggling and Illegal Excavation for Cultural Relics) ${ }^{18}$ emanate from the main executive body, the State Council. Regulations can also be made by the Ministry of Culture and by the State Bureau of Cultural Relics. ${ }^{19}$

Although the PRC is a unitary state, there is still a body of cultural propertyrelated legislation that has been developed by provincial, autonomous region, and local governments ${ }^{20}$ and by the decree of local cultural relics authorities. While such laws tend to mirror national legislation for the most part, there is often a problem of effective central administrative control and co-ordination (particularly where independently-minded coastal regions or Special Economic Zones are involved) - a current theme in PRC administration generally.

The cultural property legal regime suffers from the same inherent defects that characterise the Chinese legal system generally as 'undeveloped': a lack of legal efficacy (the gap between the statute book and the actual behaviour of citizens and officials) resulting from an absence, historically, of a concept and doctrine of legality or a legal culture; the ideology of Marxism-Leninism and particularly Mao Zedong Thought; the inadequate education of most lawrelated personnel; the tensions between policy and law; and rudimentary legal drafting and legal engineering. ${ }^{21} \mathrm{~A}$ significant portion of the legislation in the cultural property area is overlapping and too often vague and merely hortatory.

The 1982 Cultural Relics Law was meant to be the first truly comprehensive modern legislative treatment, dealing with protection of sites and immovables, archaeological excavations, state institutions, privately-owned relics, export, and enforcement. All of these areas of legislative concern have been subjected to various interpretations and glosses in numerous subsequent pronouncements and regulations. ${ }^{22}$ However the 1982 Cultural Relics Law still provides the basis of the legal regime.$$
\text { R }
$$

See note 1 above.

Issued 26 May 1987 by the State Council.

See, eg, Administrative Measures of the People's Republic of China on Foreign Archaeological Work, approved and promulgated by the State Bureau of Cultural Relics on 22 February 1991.

See, eg, Beijing Municipal Administrative Regulations on the Protection Areas for the Cultural Beijing People's Government.

22 See, eg, Detailed Rules for the Implementation of the Law of the People's Republic of China on the Protection of Cultural Relics promulgated 7 May 1992 by the State Bureau of Cultural Relics and approved by the State Council. 
The definition of 'cultural relics' is broad, covering movables and immovables of historical, artistic, or scientific value including sites, buildings, tombs, works of art, records, manuscripts, objects reflecting the various ethnic groups in different historical periods, and fossils. ${ }^{23}$ The general provisions of the legislation make no real attempt to adapt the statutory scheme or the definition to different types of protection or contexts. The definition itself is arguably subjective and vague, incorporating as it does wording like 'important' and 'valuable.' A vast amount of administrative discretion is left to the State Bureau of Cultural Relics.

All cultural relics found underground or in inland waters or territorial seas within the boundaries of the PRC are deemed to be the property of the state, as are all designated sites of ancient culture, tombs, cave temples and buildings, and collections in public institutions. ${ }^{24}$ The state has designated over five hundred sites and relics, and further designations have been made by governments at lower levels. The 1982 Law attempts to address in a very general way the tensions between the importance of site protection and the need for capital construction.

While private property rights in cultural property do exist, they are severely emasculated. Other provisions of the 1982 Law make it clear that the state has a duty to 'protect' the relics, that the items may only be sold to the state and only through the state sales apparatus, and that mandatory submission to state 'verification' procedures can result in expropriation. ${ }^{25}$

The provisions of the 1982 Law dealing with archaeological excavations ${ }^{26}$ reflect themes that pervade PRC cultural property law: the tensions between cadres charged with the responsibility for relics and those involved with construction projects, paranoia over the possible loss of relics, state concern over power exercised by local cultural relics administrations, and the general need for political units to oversee the work of departments of cultural administration.

The PRC prohibits exports of most cultural relics, but does allow for the granting of export certificates in some situations. No private individual may export any cultural relic; exports may only be made by the state sales apparatus. ${ }^{27}$ All relics must be 'verified' or examined by a cultural relics bureau. Items deemed by the state to lack historical, artistic, or cultural significance could be released for export, as could 'ordinary' cultural relics (relics not graded or deemed 'precious' by the State Bureau of Cultural Relics, on the basis of

23 See note 1 above, Art 2.

24 Ibid, Art 4.

25 Ibid, Arts 1, 2, 3, 5, 24, 25, 27, 30, and 31 .

26 Ibid, Arts 16 to 21 .

27 Ibid, Arts 27 and 28. And see Measures on the Administration of Export Verification for Cultural Relics announced 27 February 1989 by the Cultural Department, which purport, inter alia, to apply to relics held by 'compatriots in Hong Kong, Macau, Taiwan ...' (Art 11). 
unpublished guidelines). It would appear that pursuant to current administrative policy, no relics dated before 1795 will be allowed to leave China at all unless approved for exhibition loan purposes. Smuggled relics are confiscated by the state.

The 1982 Law as amended ${ }^{28}$ sets out lists of 'administrative' (quasi-criminal) and 'criminal' offences. The former include damaging relics in minor incidents, failing to report discoveries, undertaking construction in designated zones, and making illegal domestic sales. Penalties tend to be modest fines. The criminal offences include serious cases of theft, tomb-robbing, smuggling, damage, and dereliction of duty by officials. Such offences are normally dealt with harshly under the provisions of the 1980 Criminal Law of the People's Republic of China. ${ }^{29}$

There is a somewhat confusing web of legislative enactments, regulations, and edicts relating to serious cultural relics crimes and sentencing. It would appear that in serious cases the sentence ranges from ten years to life imprisonment or death..$^{30}$ One important factor in sentencing is the 'grade' of the relic, even though the prosecution (much less the accused) may not appreciate its value or significance until after the verification process by the cultural relics administration. Criminals who steal or smuggle 'Grade One' relics are often executed.

Apart from the 1982 Law and the numerous other enactments that relate to it, there is a very wide spectrum of legislation that touches on cultural property in various contexts, ${ }^{31}$ ranging from underwater relics and archaeology ${ }^{32}$ to filmmaking. ${ }^{33}$

Generally the PRC domestic regime can be characterised as one of the most stringent in the world, emphasising as it does a strict embargo approach to exports, numerous means of state control in the guise of 'protection,' and the

28 Decision on Amendments to Articles 30 and 31 of the Cultural Relics Law of the People's Republic of China adopted 29 June 1991 at the 20th Meeting of the Standing Committee of the Seventh National People's Congress.

29 See note 16 above.

30 Decision Concerning the Severe Punishment of Criminals Who Seriously Undermine the Economy adopted 8 March 1982 by the 22nd Session of the Standing Committee of the Fifth National People's Congress. See also Explanation of Several Questions Concerning the Applicable Law in Handling Cases of Stealing, Illegally Recovering, Dealing in, and Smuggling Cultural Relics, issued 27 November 1987 by the Supreme People's Court and Supreme People's Procuratorate; Supplementary Provisions Concerning the Punishment of Smuggling adopted 21 January 1988 at the 24th Session of the Standing Committee of the Sixth National People's Congress; and Supplementary Provisions on Punishment for the Crime of Illegally Excavating Ancient Cultural Relics or Tombs adopted 29 June 1991 at the 20th Meeting of the Standing Committee of the Seventh National People's Congress.

31 See Murphy, 'Annotated Chronological Index' (note 15 above).

32 See Regulations of the People's Republic of China on the Administration of Protection of Underwater Cultural Relics promulgated 20 October 1989; and Administrative Measures on Foreign Businesses Taking Part in the Salvage of Sunken Ships or Artifacts in China's Coastal Waters promulgated 12 July 1992 by the State Council.

33 See Interim Provisions on the Use of Cultural Relics and Monuments in the Filming of Motion Pictures and Television promulgated 19 April 1985 by the Ministry of Culture (apparently superceding an earlier version promulgated 11 December 1984). 
emasculation of private property rights. ${ }^{34}$ As a matter of practice, the PRC relics administration has adopted a hoarding mentality, and the overriding policy consideration is not cultural but economic - the accumulation of foreign exchange through tourism in the case of immovables, and controlled sales in the case of movables.

Historically, the PRChas, for the most part, remained aloof from the various cultural property developments in international forums. It has, however, recently acceded to the 1970 UNESCO Convention, ${ }^{35}$ the only international cultural property treaty in the civil area. Its main operative provisions are those in Article 7(a) (requiring market states to take steps to prevent their museums and similar institutions from acquiring illegally-exported cultural property from another state party) and Article 7(b) (prohibiting the importing of cultural property stolen from a museum, public monument, or institution, and obliging market states to take steps to return it). ${ }^{36}$

In addition, representatives of the PRC have recently been involved in some of the deliberations of UNIDROIT (International Institute for the Unification of Private Law) in its efforts to draft a new convention addressing the private law issues raised by the 1970 UNESCO Convention, and in particular the problem of the bona fide purchaser rule in civil law jurisdictions,

This gives rise to the response of the 'cultural internationalists' that a less retentive national policy, paradoxically, will be more effective in slowing the tide of thefts and illegal exports of antiquities. It is argued that the export policies of the source states must be guided by a cost-benefit approach, taking into account a scheme of values that ranks art objects according to their cultural significance. What is required, commentators argue, is a process of judicious selection that may result in the export of all but the most culturally significant items. The income from the export of excess relics can be made available to finance preservation of the most important pieces, training of curators, and scientific exploration efforts. Once international demand is satisfied by the creation of a sizeable licit market, the profit is cut out of illicit trafficking and the concomitant anti-social bahaviour is reduced and enforcement regimes kept to a manageable size. This sort of approach, which has at its core the substantial relaxation of export controls, would, it is argued, achieve the stated objectives of embargo legislation better than embargo legislation itself. See James A R Nafziger, 'An Anthro-Apology for Managing the International Flow of Cultural Property' (1982) 4 Houston Journal of International Law 189; Paul Bator, 'An Essay on the International Trade in Art' (1982) 34 Stanford LR 275; John HMerryman, 'The Retention of Cultural Property' (1988) 21 University of California Davis LR 477; John HMerryman and AlbertEElsen, "Hot Art: A Re-examination of the Illegal International Trade in Cultural Objects' (1982) 12 Journal of Arts Management and Law 5; and Murphy, 'The People's Republic of China and the Illicit Trade in Cultural Property' (note 3 above).

35 See note 1 above. The PRC does not appear to have enacted domestic legislation implementing the 1970UNESCO Convention; however, scholars are of the view that this is not necessary in the PRC: see Chen (note 21 above), p 103 and authorities cited therein. See useful discussions of the 1970 UNESCO Convention in John H Merryman, 'Two Ways of Thinking About Cultural Property' (1986) 80 American Journal of International Law 831; Prott andO'Keefe (note 5 above); and Maritza FBolano, 'International Art Theft Disputes: Harmonising Common Law Principles with Article 7(b) of the UNESCO Convention' (1991-2) 15 Fordham International Law Journal 129.

36 Various criticisms have been made of the 1970 UNESCO Convention, largely on the basis of its vague and subjective wording: see eg Ann P Prunty, 'Toward Establishing an International Tribunal for the Settlement of Cultural Property Disputes: How to Keep Greece From Losing Its Marbles' (1984) 72 Georgetown Law Journal 1155; Bonnie Burnham, 'Review' in (1983) 15 New York University Journal of International Law and Politics 1021, 1023; and Lalive (note 1 above). Undoubtedly the main reason for the perceived minimal impact of the 1970 UNESCO Convention is the fact that it has not been ratified by a significant number of the leading market (or transit) states, such as the United Kingdom. 
which is regarded as a major factor contributing to the illicit art trade. ${ }^{37}$ The primary aim of the draft convention is to place the responsibility on the buyer to verify that an object is being legally traded. Failure to do so will lead to the object being returned. Stolen objects are to be returned to the original owner, subject to limitations provisions and compensation being paid to the buyer where necessary diligence was shown. As to illegally exported cultural property, such objects are to be returned, but only where their export has injured certain important defined cultural interests of the state requesting their return. The draft convention in effect contributes to the creation of a new international class of property. If the convention is finalised and comes into force in 1994 or 1995 as expected, the PRC may well become a party. Clearly both the 1970 UNESCO Convention and the current UNIDROIT draft convention favour source states like the PRC, but both are based on reciprocity.

Hong Kong and 1997

After 30 June 1997, Hong Kong, a dependent territory of a leading market state and itself an important market and transit state where Chinese art and antiquities are concerned, will become a Special Administrative Region ('SAR') of the PRC. ${ }^{38}$ This raises the important question of whether after that date PRC law and administration relating to cultural relics will be extended to art and cultural property located in Hong Kong.

There is relatively little in the way of indigenous cultural property in Hong Kong. There are however very substantial collections of Chinese antiquities held privately (to the extent that they have not already been shipped out of Hong Kong to other jurisdictions for safekeeping) and in public museums. Invariably these consist largely of treasures that originated in China. There is obviously concern, not only as to whether the PRC will try to extend its administration to Hong Kong with a view to achieving more effective control of smuggling out of the PRC, but also as to whether antiquities owned by Hong Kong people or by the Hong Kong government will be 'frozen.'

There have been some preliminary statements by the PRC to the effect that this will not be the case, and that cultural property matters will be left to the SAR governments of Hong Kong and Macau. ${ }^{39}$ There was an unsuccessful attempt to include in the Basic Law of the Hong Kong Special Administrative

37 See generally Malcolm Evans, 'The International Protection of Cultural Property - The Unidroit Response' in 10th Commonwealth Law Conference Proceedings, 1993; Richard Crewdson, 'Putting Life into a Cultural Property Convention -UNIDROIT: Still Some Way to Go' (1992) 17 International Legal Practitioner 45; Lyndel V Prott, 'The Preliminary Draft Unidroit Convention on Stolen or Illegally Exported Cultural Objects' (1992) 41 ICLQ 160; and Claudia Fox, 'The Unidroit Convention on Stolen or Illegally Exported Cultural Objects: An Answer To The World Problem of Illicit Trade in Cultural Property' (1993) 9 American University Journal of International Law and Policy 225.

39 The Director of the State Council's Hong Kong and Macau Affairs Office, quoted in Xinhua, 24 September 1991. 
Region of the People's Republic of China ${ }^{40}$ a provision expressly relating to the freedom to export cultural objects. ${ }^{41}$ Significantly, and by contrast, cultural property was expressly addressed in Article 125 of the Basic Law of the Macau Special Administrative Region (enacted with a view to Macau's changeover in 1999). Article 125 provides that 'the Government of the Macau Special Administrative Region shall protect scenic spots as well as other historic relics and the legitimate rights and interests of owners of cultural relics.' This arguably would allow for the export of cultural relics from Macau after 1999.

It is of course difficult to predict what the political reality will be in 1997. This is not the place to add to the massive amount of speculation in which commentators have engaged to date. The following paragraphs provide a canvass of some provisions of the Hong Kong Basic Law that may bear on the question. ${ }^{42}$

Generally the Basic Law authorises the SAR to exercise a "high degree of autonomy. ${ }^{143}$ The 'previous capitalist system and way of life shall remain unchanged for 50 years. ${ }^{14}$ Private ownership of property is to be protected in accordance with law. ${ }^{45}$ Article 8 of the Basic Law provides that:

The laws previously in force in Hong Kong, that is, the common law, rules of equity, ordinances, subordinate legislation and customary law shall be maintained, except for any that contravene [the Basic Law], and subject to any amendment by the Legislature of the Hong Kong Special Administrative Region.

The laws in force in the SAR are to be the Basic Law, the laws previously in force in Hong Kong according to $\mathrm{BL} 8$, and the laws enacted by the legislature of the SAR ${ }^{46} \mathrm{PRC}$ national laws are not to be applied except for those listed in Annex III to the Basic Law. None listed at the moment would affect the transfer of art or cultural property. However the Standing Committee of the National People's Congress may add to the list after consulting the SAR. ${ }^{47} \mathrm{The}$

Adopted on 4 April 1990 by the Seventh National People's Congress of the People's Republic of China at its Third Session (hereinafter, the 'Basic Law').

41 South China Morning Post, 26 October 1993, quoting the Chairman of Sothebys Asia.

42 See generally Roda Mushkat, 'Hong Kong as an International Legal Person' (1992) 6 Emory International Law Review 105; and Yash Ghai and Peter Wesley-Smith, 'Constitutional and Legal System' in Philip Smart and Andrew Halkyard (eds), Trade and Investment Law in Hong Kong (Singapore: Butterworths Asia, 1993) and references cited therein. As to 1997 generally, see Raymond Wacks (ed), The Future of the Law in Hong Kong (Hong Kong: Oxford University Press, 1989); Peter Wesley-Smith and Albert Chen (eds), The Basic Law and Hong Kong's Future (Singapore: Butterworths, 1988); and Peter Wesley-Smith (ed), Hong Kong's Transition: Problems \&̊ Prospects (Hong Kong: Faculty of Law, University of Hong Kong, 1993).

43 Basic Law (BL), Art 2. (See pp 173-80 above.)

44 BL5.

45 BL6.

46 BL18.

47 Ibid. 
Standing Committee may also declare any Hong Kong laws to be in contravention of the Basic Law. ${ }^{48}$

Article 22 provides that no department of or political unit within the PRC may interfere in SAR affairs. The government of the PRC shall, however, have responsibility for foreign affairs relating to the SAR. ${ }^{49}$

Article 115 provides that the SAR shall pursue the policy of free trade and 'safeguard the free movement of goods, intangible assets and capital.' Article 116 stipulates that the SAR shall be a separate customs territory. Article 140 provides that the SAR shall formulate its own policies on culture.

As can be seen, there is no express mention of cultural property in the Basic Law. However, on the face of the Basic Law at least, it would appear that PRC laws relating to cultural property will not be extended to the SAR unless the legislature of the SAR does so, additions are made to Annex III, or the matter is somehow regarded as being encompassed within foreign affairs. If this view is correct, the status quo will pertain after 1997. That is, the stringent (at least de jure) domestic and export regime will continue in the territory of the PRC, and the relatively lax regime will continue in the SAR territory. Chinese antiquities located in Hong Kong will be secure from the application of PRC laws and administration, and there will still be an incentive to smuggle relics through Hong Kong into world markets. Legal repatriation efforts by the PRC will be limited to the common law remedies, such as replevin (subject of course to a sufficient evidentiary base), afforded by existing Hong Kong law, though China has not shown an inclination to resort to this in the past.

The PRC has acceded to the 1970 UNESCO Convention and has demonstrated an interest in the draft UNDROIT convention which would be a supplement to the former. The United Kingdom is not likely to accede to either before 1997. However, it should be noted that Article 153 of the Basic Law provides that the application to the SAR of international agreements to which the PRC is a party shall be decided by the government of the PRC 'in accordance with the circumstances and needs of the Region, and after seeking the views of the government of the Region.' A possible scenario is that after 1997 the PRC will cause international cultural property conventions to which it is a party to be applied to the SAR as well. The PRC could then attempt to avail itself of the repatriation and other provisions in such conventions, on the basis that the PRC and the Hong Kong SAR are separate customs territories, ${ }^{50}$ in order to force the return of antiquities. It should be noted, however, that under these conventions the safeguards for possessors of the targeted cultural

49 BL11.

50 See Mushkat (note 42 above) and Roda Mushkat, 'Jurisdictional Issues in a "Highly Autonomous Region"-The Case of Hong Kong' (1993) 42 ICLQ11 for arguments to this effect in other contexts. 
property, while not as extensive as some would like, are significantly greater than under PRC domestic law.

Quite apart from the BL153 scenario, there is another avenue potentially available to the PRC that could well prove worrisome for market interests in Hong Kong. It arises from the seemingly innocuous Article 12 of the 1970 UNESCO Convention, ironically a vestige of colonial times:

The States Parties to this Convention shall respect the cultural heritage within the territories for the international relations of which they are responsible, and shall take all appropriate measures to prohibit and prevent the illicit import, export and transfer of ownership of cultural property in such territories (emphasis supplied).

Of course the existence of the unique Chinese 'special administrative regions' was hardly in the contemplation of the drafters of the 1970 UNESCO Convention. However it is not inconceivable that the PRC, which clearly will have power over the foreign affairs of the SAR, could seize upon the positive treaty obligation set forth in Article 12 and use it as an authority for its interference in cultural property matters in Hong Kong. This is particularly significant as Article 12 is expressed much more broadly than other operative provisions such as Article 7.

The international movement of art and antiquities is not normally the first topic that comes to mind when the concerns over 1997 are raised. However, it cannot be doubted that the movement of cultural property has economic, political, and cultural implications for this region just as it does elsewhere in the world. It is to be hoped that whatever the relationship between the PRC and Hong Kong after 1997, the policies adopted in the cultural property area will be enlightened and will properly balance the often-competing domestic and international concerns and objectives.

J David Murphy*

* Lecturer, Department of Law, University of Hong Kong. 